\title{
Hyperhomocysteinemia and primary antiphospholipid syndrome
}

\author{
Jozélio Freire de Carvalho, ${ }^{1,2}$, Maria Teresa Correia Caleiro², Eloísa Bonfá ${ }^{3}$
}

\begin{abstract}
Objectives: The objective of this study was to investigate the prevalence of hyperhomocysteinemia and its possible clinical and laboratorial associations in patients with primary antiphospholipid syndrome (PAPS). Patients and methods: This is a transversal study with 27 patients ( $88 \%$ women) with PAPS (Sapporo criteria). Demographic and clinical data, as well as comorbidities, medications, antiphospholipid antibodies, and blood concentrations of homocysteine, measured by high resolution liquid chromatography, were evaluated. Results: Six (22\%) out of 27 patients had high levels of homocysteine $(98.7 \pm 8.9$ versus $8.0 \pm 2.9 \mu \mathrm{M}, \mathrm{P}=0.0008)$. Comparison between the group of patients with hyperhomocysteinemia and the group of patients with normal serum homocysteine levels did not show differences in the demographic data (age, white, weight, height, and body mass index) or in the duration of the disease (64 \pm 39.6 versus $77.9 \pm 61.3$ months, $\mathrm{P}=0.32$ ). Differences in disease manifestations (arterial, venous, and obstetric events, deep venous thrombosis, pulmonary thromboembolism, thrombocytopenia, acute myocardial infarction, angina, and stroke), comorbidities (hypertension and hyperlipidemia), life style (physical activity, past and present smoking), as well as the use of medications (past and present use of corticosteroids, statins, chloroquine, and acetylsalicylic acid), were not observed between both groups. The prevalence and titers of anticardiolipin antibodies were similar in both groups of patients. Conclusion: Hyperhomocysteinemia can be detected in approximately one fourth of the PAPS patients, and it is not associated with distinct clinical and laboratorial characteristics of this disorder.
\end{abstract}

Keywords: primary antiphospholipid syndrome, hyperhomocysteinemia, thrombosis, clinical.

\section{INTRODUCTION}

Antiphospholipid syndrome (APS) is an acquired autoimmune thrombophilia characterized by the presence of vascular thrombosis and/or obstetric events, associated or not with thrombocytopenia in the presence of persistent moderate levels of antiphospholipid antibodies. ${ }^{1}$

Recently, this syndrome has been associated with the presence of premature atherosclerosis and coronary events. ${ }^{2}$ It has been shown that traditional risk factors for cerebrovascular diseases are associated with APS; however, the role of other non-traditional risk factors has not been extensively studied. Homocysteine, a sulfhydryl acid formed during the metabolism of methionine, which in high levels can cause endothelial toxicity and activate the coagulation system, has been associated with atherosclerosis and cerebral ischemia. ${ }^{3,4}$ Few studies have evaluated the presence of hyperhomocysteinemia in patients with primary antiphospholip syndrome(PAPS), and most of them included patients with systemic lupus erythematosus (SLE) or did not exclude secondary conditions that could influence the serum levels of this amino acid..$^{5-7}$

The objective of this study was to investigate the prevalence of hyperhomocysteinemia in a population of patients with PAPS and to evaluate the possible association with clinical and laboratorial findings of this disorder.

\section{PATIENTS AND METHODS}

In this study it were included twenty-seven consecutive patients of both genders, ages 18 to 55 years, diagnosed with

Received on 11/26/2008. Approved on 03/11/2009. We declare no conflict of interests.

1. Collaborator Professor of Rheumatology from the School of Medicine (FMUSP)

2. Attending Physician of the Rheumatology Department (HC-FMUSP)

3. Professor of the Rheumatology Department (HC-FMUSP)

Correspondence to: Jozélio Freire de Carvalho. Rheumatology Department (FMUSP). Av. Dr. Arnaldo, 455, 3º andar, sala 3.190, São Paulo, SP, Brazil — CEP: 01246-903. Phone/Fax: 5511 3061-7490. E-mail: jotafc@gmail.com 
PAPS according to the Sapporo criteria. ${ }^{8}$ These patients were followed at the APS outpatient clinic of the Hospital das Clínicas Rheumatology Department at School of Medicine at Universidade de São Paulo (HC-FMUSP).

Data used in this study were collected in the evaluation visit, and the medical charts were also reviewed. Arterial and venous clinical events were confirmed by imaging methods, such as echo-Doppler, ventilation-perfusion scintigraphy, CT scan, MRI, arteriography, angiotomography, and angio-MRI. Thrombocytopenia was defined as a platelet level $<100,000 / \mathrm{mm}^{3}$ at least in two different consecutive occasions. The presence of comorbidities, such as arterial systemic hypertension ( $\mathrm{BP} \geq 140$ x $90 \mathrm{mmHg}$ or use of anti-hypertensive drugs), hyperlipedemias, and drugs used, were also evaluated. The presence and titers of anticardiolipin IgG and IgM antibodies were determined at the clinical diagnosis of the syndrome.

Exclusion criteria included conditions that change the levels of homocysteine, such as chronic renal failure, malignancies, advanced age ( $>55$ years), systemic lupus erythematosus, and the use of vitamin B12 and folic acid.

Detection of anticardiolipin antibodies: Anticardiolipin IgG and IgM antibodies were detected by indirect ELISA. ${ }^{9}$ Briefly, wells of polystyrene microplates were sensitized with $50 \mu \mathrm{g} / \mathrm{mL}$ of cardiolipin (Sigma Chem. Co., USA) in cold ethanol $(50 \mu \mathrm{L} /$ well $)$ for 16 hours at $4{ }^{\circ} \mathrm{C}$. After being washed, the plate was blocked by two hours with inactive fetal bovine serum $\left(56^{\circ} \mathrm{C}\right.$ for 30 minutes) at $30 \%$ in PBS. The wells were incubated sequentially in duplicate, with the diluted serum at 1:50 and goat polyclonal IgG antibodies anti-human IgG or IgM tagged with peroxidase (Sigma Chem. Co., USA). Results were expressed in GPL and MPL units, determined by the curve plotted from the absorbance values obtained from internationally defined reference serum samples. Levels above $20 \mathrm{U}$, according to the Sapporo criteria, were considered diagnostic of the syndrome. ${ }^{8}$

The presence of lupus anticoagulant (LAC) was determined by functional hematological tests: the activated partial thromboplastin time (aPTT) was used for the initial screening, followed by Russell's viper venom time. If the results were abnormal, the mixing test, a combination of $50 \%$ normal plasma and 50\% test plasma, was performed; a correction of the aPTT was diagnostic of coagulation factor deficiency. Otherwise, if there was no correlation, and this was achieved with a mixture of plasma rich in phospholipids (platelets), the diagnosis of LAC was made.

Homocysteine levels: a blood sample was drawn after a 12-hour fasting period to determine the homocysteine levels. The sample was stored in ice and centrifuged immediately at $0{ }^{\circ} \mathrm{C}$ to separate the plasma. The levels of homocysteine were determined by reverse phase high resolution liquid chromatography (Shimadzu Class-Vp System), a technique described by Fiskerstrand et al. ${ }^{10}$ Levels above $15 \mu \mathrm{M}$ were considered elevated.

Statistical analysis: results were shown as means and standard deviation. GraphPadInStat, version 2.00, was used for the statistical analysis; Student's t-test was used to compare means, and Fisher's exact test was used for the frequencies. Results were considered significant when $\mathrm{P}<0.05$.

\section{RESULTS}

The mean age of the 27 patients with APS was $38.6 \pm 9.7$ years; 23 patients were females $(85.2 \%)$ and $81.5 \%$ were white. The mean duration of the disease was $75.1 \pm 57.1$ months. Regarding vascular events, $66.7 \%$ had arterial thrombosis; $48.2 \%$, venous thrombosis; and $14.8 \%$, thrombocytopenia.

Six $(22 \%)$ of the 27 patients had increased levels of homocysteine $(>15 \mu \mathrm{M})$. Mean levels in this group were statistically higher than in the group with normal homocysteine ( $98.7 \pm 8.9$ versus $8.0 \pm 2.9 \mu \mathrm{M}, \mathrm{P}=0.0008)$. Comparing the group of patients with hyperhomocysteinemia with those with normal levels of homocysteine, significant differences in age, female gender, white race, and mean weight, height and body mass index, as well as duration of the disease, were not observed (Table 1).

As for clinical manifestations of the disease and comorbidities, both groups of patients were similar regarding arterial, venous, and obstetric events, pulmonary thromboembolism, thrombocytopenia, stroke, Sneddon syndrome, ischemia of the extremities, acute myocardial infarction, angina, deep venous thrombosis, arterial systemic hypertension, hyperlipedemias, and osteonecrosis. Life style, i.e., the frequency of physical activities, and current and past smoking, was also similar between both groups (Table 2).

Both groups were also similar regarding drug use: corticosteroids (current and past use), chloroquine, warfarin, statins, and acetylsalicylic acid (Table 3).

The frequency of lupus anticoagulant and $\operatorname{IgG}$ and $\operatorname{IgM}$ anticardiolipin antibodies was also similar in both groups, as well as their means. (Table 4).

\section{DISCUSSION}

This study showed the presence of hyperhomocysteinemia in approximately one fourth of the patients with primary 


\section{Table 1}

Comparison of the demographic and anthropometric data and the duration of disease in patients with primary antiphospholipid syndrome (PAPS) according to the homocysteinemia

\begin{tabular}{|c|c|c|c|}
\hline Data & $\begin{array}{c}\text { PAPS } \\
\text { Homocysteine } \\
\geq 15 \mu M \\
N=6\end{array}$ & $\begin{array}{c}\text { PAPS } \\
\text { Homocysteine } \\
<15 \mu \mathrm{M} \\
\mathrm{N}=21\end{array}$ & $\mathbf{P}$ \\
\hline Age (years) & $42.5 \pm 9.5$ & $37.5 \pm 9.7$ & 0.27 \\
\hline Female, n (\%) & $5(83)$ & $18(85.7)$ & 1.00 \\
\hline White, n (\%) & $6(100)$ & $16(76)$ & 0.56 \\
\hline Weight (kg) & $67.4 \pm 9.9$ & $74.7 \pm 18.5$ & 0.18 \\
\hline Height $(\mathrm{cm})$ & $157.2 \pm 8.4$ & $161.2 \pm 8.8$ & 0.33 \\
\hline $\begin{array}{l}\text { Body mass } \\
\text { index }\left(\mathrm{kg} / \mathrm{cm}^{2}\right)\end{array}$ & $27 \pm 2.9$ & $28.4 \pm 6.4$ & 0.61 \\
\hline $\begin{array}{l}\text { Disease duration } \\
\text { (months) }\end{array}$ & $64 \pm 39.6$ & $77.9 \pm 61.3$ & 0.32 \\
\hline
\end{tabular}

Data presented as mean \pm standard deviation or percentages. Student's t-test was used to compare means; Fisher's exact test was used for frequencies.

antiphospholipid syndrome evaluated in the APS outpatient clinic of the Rheumatology Department of HC-FMUSP.

Increased levels of homocysteine, a thiol-amino acid produced by the demethylation of methionine, have been associated with endothelial dysfunction, and it can interfere with the protein $\mathrm{C}$ anticoagulation pathway, by reducing the synthesis of thrombomodulin and binding to thrombin, leading to resistance to activated protein C. ${ }^{11,12}$

Several conditions can cause changes in the levels of homocysteine, such as nephrotic syndrome, chronic renal failure, systemic lupus erythematosus, hypothyroidism, vitamin B12 and folic acid supplementation. In the present study, these conditions were excluded to guarantee the clinical relevance of the results. ${ }^{13}$

Several studies have evaluated the presence of homocysteinemia in patients with or without antiphospholipid syndrome. ${ }^{14,15}$ One of this article's authors participated in a recent Brazilian study, which evaluated cardiovascular risk factors in APS, the presence of hyperhomocysteinemia was not properly investigated. However, preliminary observations suggested that patients with PAPS and arterial thrombosis could have higher serum levels of homocysteine than the control population. ${ }^{16}$ However, in this study, statistically significant differences were not observed in the serum levels of homocysteine in patients with PAPS and thrombosis when compared with patients who did not have those manifestations.
Table 2

Comparison of the clinical data, cardiovascular events, comorbidities, and life style of patients with primary antiphospholipid syndrome (PAPS) according to the homocysteinemia

\begin{tabular}{|c|c|c|c|}
\hline Dados & $\begin{array}{c}\text { PAPS } \\
\text { Homocysteine } \\
\geq 15 \mu \mathrm{M} \\
\mathrm{N}=6\end{array}$ & $\begin{array}{c}\text { PAPS } \\
\text { Homocysteine } \\
<15 \mu M \\
N=21\end{array}$ & $\mathbf{P}$ \\
\hline Arterial events, n (\%) & $5(83.3)$ & 13 (61.9) & 0.63 \\
\hline Venous events, n (\%) & $2(33.3)$ & $11(52.4)$ & 0.65 \\
\hline $\begin{array}{l}\text { Obstetric } \\
\text { events, n (\%) }\end{array}$ & $1(16.6)$ & $3(14.3)$ & 1.00 \\
\hline Stroke, n (\%) & $5(83.3)$ & $9(42.8)$ & 0.16 \\
\hline $\begin{array}{l}\text { Sneddon } \\
\text { syndrome, n (\%) }\end{array}$ & $2(33.3)$ & $5(23.8)$ & 0.63 \\
\hline $\begin{array}{l}\text { Ischemia of the } \\
\text { limbs, } n(\%)\end{array}$ & $2(33.3)$ & $5(23.8)$ & 0.63 \\
\hline $\begin{array}{l}\text { Acute myocardial } \\
\text { infarction, } \mathrm{n}(\%)\end{array}$ & 0 & $2(9.5)$ & 1.00 \\
\hline Angina, $\mathrm{n}(\%)$ & $1(16.6)$ & $1(4.7)$ & 1.00 \\
\hline $\begin{array}{l}\text { Deep venous } \\
\text { thrombosis, } \mathrm{n}(\%)\end{array}$ & $2(33.3)$ & $11(52.4)$ & 0.65 \\
\hline $\begin{array}{l}\text { Pulmonary } \\
\text { thromboembolism, } \\
\mathrm{n}(\%)\end{array}$ & $1(16.6)$ & $3(14.3)$ & 1.00 \\
\hline $\begin{array}{l}\text { Thrombocytopenia, } \\
\text { n (\%) }\end{array}$ & 0 & $4(19.0)$ & 0.55 \\
\hline $\begin{array}{l}\text { Arterial systemic } \\
\text { hypertension, n (\%) }\end{array}$ & $4(66.6)$ & $8(38.1)$ & 0.36 \\
\hline $\begin{array}{l}\text { Hyperlipedemia, } \\
\text { n }(\%)\end{array}$ & $2(33.3)$ & $8(38.1)$ & 1.00 \\
\hline Physical activity, n (\%) & $2(33.3)$ & $5(23.8)$ & 0.63 \\
\hline $\begin{array}{l}\text { Current smoking, } \\
\mathrm{n}(\%)\end{array}$ & 0 & $3(14.3)$ & 1.00 \\
\hline Past smoking, n (\%) & $2(33.3)$ & $9(42.8)$ & 1.00 \\
\hline
\end{tabular}

Fisher's exact test was used to compare frequencies.

Lee et al. reported similar finding; they found a $14 \%$-incidence of hyperhomocysteinemia in women with APS, which did not differ from the control group, and it did not show any association with the clinical or laboratorial manifestations of the disease. ${ }^{17}$

In the study of Del Ross et al., hyperhomocysteinemia was detected in 10 out of 29 patients with PAPS. Nine of those patients had a history of cerebrovascular disease. ${ }^{18}$ It is important to emphasize that the authors did not exclude 
Table 3

Comparison of the frequency of medications used by patients with primary antiphospholipid syndrome (PAPS) according to the homocysteinemia

\begin{tabular}{|c|c|c|c|}
\hline Data & $\begin{array}{c}\text { PAPS } \\
\text { Homocysteine } \\
\geq 15 \mu \mathrm{M} \\
\mathrm{N}=6\end{array}$ & $\begin{array}{c}\text { PAPS } \\
\text { Homocysteine } \\
<15 \mu \mathrm{M} \\
\mathrm{N}=21\end{array}$ & $\mathbf{P}$ \\
\hline $\begin{array}{l}\text { Current use of } \\
\text { corticosteroids, } \\
\mathrm{n}(\%)\end{array}$ & $1(16.6)$ & $1(4.7)$ & 0.40 \\
\hline $\begin{array}{l}\text { Past use of } \\
\text { corticosteroids, } \\
\mathrm{n}(\%)\end{array}$ & $3(50)$ & $11(52.4)$ & 1.00 \\
\hline $\begin{array}{l}\text { Use of warfarin, } \\
\mathrm{n}(\%)\end{array}$ & $4(66.6)$ & 17 (80.9) & 0.59 \\
\hline $\begin{array}{l}\text { Use of } \\
\text { chloroquine, } \\
\mathrm{n}(\%)\end{array}$ & 1 (16.6) & $8(38.1)$ & 0.63 \\
\hline $\begin{array}{l}\text { Use of statins, } \\
\mathrm{n}(\%)\end{array}$ & $3(50)$ & $7(33.3)$ & 0.64 \\
\hline $\begin{array}{l}\text { Current use of } \\
\text { acetylsalicylic } \\
\text { acid, n (\%) }\end{array}$ & $1(16.6)$ & $6(28,6)$ & 1.00 \\
\hline
\end{tabular}

Fisher's exact test was used to compare frequencies.

secondary conditions, such as renal failure and systemic lupus erythematosus, which interfere with the serum levels of homocysteine.

In a similar study, Avivi et al. investigated the plasma levels of homocysteine in 52 patients with PAPS and found hyperhomocysteinemia in $30.8 \%$ of the cases. The authors concluded that the elevated levels of homocysteine were associated with a higher risk of thromboembolic events. ${ }^{19}$ However, conditions that could cause changes in the levels of homocysteine were not excluded.

In conclusion, the present study showed that a proportion of the patients with primary antiphospholipid syndrome can have elevated serum levels of homocysteine. However, this finding was not associated with the clinical and laboratorial manifestations of the disease or with the presence of cerebral and cardiovascular comorbidities in the study population. This could be due to the low number of patients with hyperhomocysteinemia in this study. Thus, prospective studies with a larger number of patients with elevated homocysteine serum levels are necessary to evaluate the effects of hyperhomocysteinemia in patients with APS.

\section{REFERENCES}

1. Hughes GR. Thrombosis, abortion, cerebral disease, and the lupus anticoagulant. Br Med J (Clin Res Ed) 1983;287:1088-9.
Table 4

Comparison of the frequencies of antinuclear factor and antiphospholipid antibodies in patients with primary antiphospholipid syndrome (PAPS) according to the homocysteinemia

\begin{tabular}{lccc}
\hline & $\begin{array}{c}\text { PAPS } \\
\text { Homocysteine } \\
\mathbf{1 5} \boldsymbol{\mu} \mathbf{M} \\
\mathbf{N}=\mathbf{6}\end{array}$ & $\begin{array}{c}\text { PAPS } \\
\text { Homocysteine } \\
<\mathbf{1 5} \mathbf{~} \mathbf{M}\end{array}$ & $\mathbf{P}$ \\
\hline Data & $4(80)$ & $\mathbf{N}=\mathbf{2 1}$ & 0.63 \\
\hline $\begin{array}{l}\text { Lupus } \\
\text { anticoagulant, } \\
\mathrm{n}(\%)\end{array}$ & $31 \pm 46.5$ & $16(76)$ & 0.35 \\
$\begin{array}{l}\text { IgG aCL, GPL } \\
\text { IgM aCL, MPL }\end{array}$ & $28.2 \pm 46.6$ & $36.3 \pm 22.6$ & 0.70 \\
$\begin{array}{l}\text { Presence of } \\
\text { IgG aCL, } \mathrm{n}(\%)\end{array}$ & $3(50)$ & $12(57)$ & 1.00 \\
$\begin{array}{l}\text { Presence of } \\
\text { IgM aCL, } \mathrm{n}(\%)\end{array}$ & $3(50)$ & $12(57)$ & 1.00 \\
$\begin{array}{l}\text { Presence of IgG } \\
\text { or IgM aCL }\end{array}$ & $3(50)$ & $17(80.9)$ & 0.29 \\
\hline
\end{tabular}

Data presented as mean \pm standard deviation or percentage. $\mathrm{aCL}$ : anticardiolipin antibody. Student's t-test was used to compare means; Fisher's exact test was used to compare frequencies.

2. Jara LJ, Medina G, Vera-Lastra O. Systemic antiphospholipid syndrome and atherosclerosis. Clin Rev Allergy Immunol 2007;32:172-7.

3. Bots ML, Launer LJ, Lindemans J, Hoes AW, Hofman A, Witteman $\mathrm{JC}$ et al. Homocysteine and short-term risk of myocardial infarction and stroke in the elderly: the Rotterdam Study. Arch Intern Med 1999; 159:8-44.

4. Adachi H, Hirai Y, Fujiura Y, Matsuoka H, Satoh A, Imaizumi T. Plasma homocysteine levels and atherosclerosis in Japan: epidemiological study by use of carotid ultrasonography. Stroke 2002;33:2177-81.

5. Onetti L, Villafañe S, Menso E. Hyperhomocysetinemia as a thrombotic risk factor in patients suffering from systemic lupus erythematosus and antiphospholipid syndrome. Rev Fac Cien Med Univ Nac Cordoba 2005;62:19-23.

6. Reshetniak TM, Shirokova IE, Lisitskaia TL. The role of hyperhomocysteinemia in systemic lupus erythematosus and antiphospholipid syndrome. Ter Arkh 2006;78:24-30.

7. Martínez-Berriotxoa A, Ruiz-Irastorza G, Egurbide MV, Rueda M, Aguirre C. Homocysteine, antiphospholipid antibodies and risk of thrombosis in patients with systemic lupus erythematosus. Lupus 2004;13:927-33.

8. Wilson WA, Gharavi AE, Koike T, Locksin MD, Branch DW, Piette JC et al. International consensus statement on preliminary classification criteria for definite antiphospholipid syndrome: report of an international workshop. Arthritis Rheum 1999; 42:1309-11.

09. Gharavi AE, Harris EN, Asherson RA, Hughes GRV. Anticardiolipin antibodies: isotype distribution and phospholipid specificity. Ann Rheum Dis 1987;46:1-6. 
10. Fiskerstrand T, Refsum H, Kvalheim G, Ueland PM. Homocysteine and other thiols in plasma and urine: automated determination and sample stability. Clinical Chemistry 1993;39:263-71.

11. Undas A, Brozek J, Szczeklik A. Homocysteine and thrombosis: from basic science to clinical evidence. Thromb Haemost 2005;4:7-15.

12. Ebbesen LS. Hyperhomocysteinemia, thrombosis and vascular biology. Cell Mol Biol 2004;50:917-30.

13. Santos RD, Martinez LRC, Cavalheiro C, Machado César LA. "Novos fatores de risco". In: Nobre F, Serrano Jr. CV. Tratado de cardiologia SOCESP, 1 ed. São Paulo: Manole, 2005.

14. Chen WH, Lin HS, Kao YF, Lan MY, Liu JS. Hyperhomocysteinemia relates to the subtype of antiphospholipid antibodies in non-SLE patients. Clin Appl Thromb Hemost 2007;13:398-403.

15. Kassis J, Neville C, Rauch J. Antiphospholipid antibodies and thrombosis: association with acquired activated protein $\mathrm{C}$ resistance in venous thrombosis and with hyperhomocysteinemia in arterial thrombosis. Thromb Haemost 2004;92:1312-19.
16. de Souza AW, Silva NP, de Carvalho JF, D’Almeida V, Noguti MA, Sato EI. Impact of hypertension and hyperhomocysteinemia on arterial thrombosis in primary antiphospholipid syndrome. Lupus 2007; 16:782-7.

17. Lee RM, Brown MA, Ward K, Nelson L, Branch DW, Silver RM. Homocysteine levels in women with antiphospholipid syndrome and normal fertile controls. J Reprod Immunol 2004;63:23-30.

18. Del Ross T, Ruffatti A, Tonello M. Primary antiphospholipid syndrome and hyperhomocysteinemia: a study of a group of 29 patients. Reumatismo 2006;58:375-867.

19. Avivi I, Lanir N, Hoffman R, Brenner B. Hyperhomocysteinemia is common in patients with antiphospholipid syndrome and may contribute to expression of major thrombotic events. Blood Coagul Fibrinolysis 2002;13:169-72. 